Криштопа С.І., Криштопа Л.І., Гнип М.М., Микитій І.М., Мельник В.М., Дикун Т.В. Івано-Франківській національний технічний університет нафти і газу

\title{
ДОСЛІДЖЕННЯ СКЛАДУ І ТЕПЛОТИ ЗГОРАННЯ ПІРОЛІЗНИХ ГАЗІВ ЯК ПАЛИВА ДЛЯ КОНВЕРТОВАНИХ НА ГАЗ ДИЗЕЛЬНИХ ДВИГУНІВ НАФТОГАЗОВОГО ТЕХНОЛОГІЧНОГО ТРАНСПОРТУ
}

\begin{abstract}
| Досліджені енергетичні цінності газоподібних продуктів піролізу типової лісової та водної рослинної біомаси України. Проведені теоретичні дослідження основних характеристики зразків типової рослинної біомаси України: акації, ліщини, мікроцистіса, елодеї. Сформульовані методика та планування експериментальних досліджень процесу піролізу рослинної біомаси. Виконані в лабораторних умовах експериментальні дослідження складу газоподібних продуктів піролізу різних видів рослинної біомаси для різних температур. Піроліз рослинної біомаси проводився з використанням спеціально спроектованої та виготовленої піролізної установки, головною частиною якої є піролізний реактор. Виготовлена установка призначена для повільного піролізу. У дослідженні для визначення факту присутності і процентного виходу продукту були використані якісний і кількісний аналізи газової хроматографії. Розраховані нижчі теплотворні здатності газоподібних продуктів піролізу зразків типової лісової та водної рослинної біомаси України. В результаті проведених розрахунків визначено, що при піролізі водних рослин та водорості суміш одержаних газів мала найвищі показники нижчої теплотворної здатності: 17,10-17,15 МДж/кг - для мікроцистіса і 16,4516,50 МДж/кг - для елодеї. Газ одержаний при піролізі деревини акації мав найвищі показники нижчої теплотворної здатності в межах від 13,8 до 13,85 МДж/кг. Нижча теплотворна здатність пірогазу отриманого зі зразків ліщини перебувала в діапазоні 12,6-12,65 МДж/кг.

Ключові слова: піроліз, нижча теплотворна здатність, газова хроматографія, альтернативні палива, дизельний двигун, конвертація двигуна на газ.
\end{abstract}

\section{ВСТУП}

Протягом століть людство використало біомасу як джерело енергії. Біомаса може забезпечити великі обсяги корисної енергії, набагато менше при цьому, в порівнянні з викопним паливом, впливаючи на навколишнє середовище. Саме тому багато років ведуться численні дослідження систем для конвертації біомаси в різні види палива для двигунів внутрішнього згорання. Перспективи масштабного використання біомаси також викликані необхідністю покращень навколишнього середовища. Піроліз та інші процеси термохімічної конверсії $є$ ефективними способами утилізації біомаси. Зростаюча залежність України від імпорту нафти визначають напрямок нової енергетичної політики, орієнтованої на використання поновлюваних джерел енергії. В Україні відомі проекти та розробки із застосування біомаси, але незважаючи на це, темпи розвитку комерційного використання біомаси в нашій країні є невисокі. Щоб максимально використати переваги технології термічної конверсії біомаси для використання біопалив на транспорті необхідно проводити в цьому напрямку масштабні дослідження.

\section{АНАЛІЗ ЛІТЕРАТУРНИХ ДАНИХ ТА ПОСТАНОВКА ПРОБЛЕМИ \\ Біоматеріали для біопалив}

В даний час ряд авторів вважає, що біомаса забезпечує енергією близько 10-14 \% споживачів в світі. Близько $25 \%$ енергії біомаси припадає на промислово розвинені країни, а решта $75 \%$ на країни, що розвиваються [1]. Очевидно, що біоенергетика не може повністю замінити викопні види палива. Проте, iï використання може частково знизити викиди $\mathrm{CO}_{2}$ i замінити нафту. Деревина $\epsilon \mathrm{CO}_{2}$ нейтральним паливом, за умови, що дерев вирощують стільки, скільки вирубують. Крім того, для вирубки, трансформації та перетворення деревини в теплову енергію потрібна робоча сила. Розвиток лісової промисловості для енергетичних цілей сприяє зайнятості місцевого населення і підтримки соціальної і економічної діяльності в сільських і лісових районах України.

Енергія сонячного світла перетворюється в рослинах в процесі фотосинтезу для створення джерел енергії у вигляді складних вуглеводнів, водню і кисню, сполук, які називаються цукром i вуглеводами. Рослини, вирощені для виробництва продуктів харчування, містять крохмаль або цукор, а також структури компонентів (наприклад, стовбури, стебла, листя). Перше покоління біопалива отримували 3 харчової біомаси (цукор і крохмаль), а в другому поколінні біопалива отримують шляхом переробки залишкових структурних біомас з відходів харчової промисловості [2].

Структурні компоненти біомаси складаються 3 основних хімічних структурних блоків деревини: целюлози, геміцелюлози і лігніну. 3 цієї причини непродовольча частка біомаси, 
називається лігноцелюлозною біомасою. Деревні компоненти лігноцелюлозних біомас переплітаються в складні композитні матриці, які створюють різні структурні компоненти (наприклад, стовбур дерева, кукурудзяні стебла). Целюлоза і геміцелюлоза $є$ волокнами зміцнення структури біомаси [3].

Тип біомаси в основному залежить від суми кожного з цих компонентів. В цілому, частка компонентів біомаси варіюється в залежності від типів біомаси. Біомаса складається в основному 3 вуглецю, водню і кисню, а при повному спалюванні залишаються вода і вуглекислий газ. Отримана вода і водяна пара містять багато прихованої теплоти, яка виділяється при конденсації. Майже у всіх видів лігноцелюлозної сировини біомаси теплотворна здатність знаходиться в межах 15-19 МДж/кг, а ii значення для більшості деревних матеріалів складає 15-17 МДж/кг. Основним компонентом деревини $є$ целюлоза. Вона займає близько 45 \% маси в твердих і м'яких породах деревини [4].

Целюлоза - це сильний, нерозгалужений полімер глюкози цукру, який міститься в рослинній клітинної стінки. Цей довгий ланцюг молекули, часто від 5000 до 15000 кілець глюкози, полімеризується в одну молекулу целюлози $\left(\mathrm{C}_{6} \mathrm{H}_{10} \mathrm{O}_{5}\right)_{\mathrm{n}}$, де $\mathrm{n}$ - довжина полімеру целюлози. Целюлозні волокна вбудовані подібно тканим матам в біомасу і іiі хімічну структуру [5].

Геміцелюлоза також знаходиться в стінках рослинної клітини. Вона складається з сильно розгалужених полімерів структури, таких як глюкоза та інші цукри, багато з яких містять п'ять атомів вуглецю. Геміцелюлоза характеризується більш низькою молекулярною вагою, ніж целюлоза. Вона складається тільки з 500-3000 одиниць цукру і має більш короткий ланцюг, ніж целюлоза. Сурогатної молекулою для геміцелюлози є $\mathrm{C}_{4} \mathrm{H}_{5.9} \mathrm{O}_{3.3}$, ця формула була запропонована в роботі [6].

Лігнін займає простір клітинної стінки рослин, заповнюючи обсяг навколо гілок і ланцюги геміцелюлози і целюлози. Він ковалентно пов'язаний з геміцелюлозою, в результаті чого складає лігноцелюлозну матрицю, а отже, i всю підсумкову структуру рослини. Лігнін може бути представлений у вигляді комбінації двох хімічних груп: $\mathrm{C}_{9}$-групи і $\mathrm{OCH}_{3}$, метокси $(\mathrm{MeO})$ групи. Молекулярна формула для лігніну записується у вигляді: $\mathrm{C}_{9} \mathrm{H}_{10} \mathrm{O}_{2}\left(\mathrm{OCH}_{3}\right)_{\mathrm{r}}$, де $\mathrm{r}$ являє собою відношення метокси групи і фенілпропаноїдної групи. Це співвідношення залежить від вихідної сировини [7].

\section{Продукти піролізу}

Суміш піролізних газів складається 3 декількох горючих газів: $\mathrm{CO}_{2}, \mathrm{CO}, \mathrm{H}_{2}, \mathrm{CH}_{4}$, гідрокарбонатів, слідів $\mathrm{N}_{2}, \mathrm{C}_{2}-\mathrm{C}_{6}$ і сульфатів. Кількість газу залежить від багатьох факторів, включаючи тип реактора, сировини і переробки залишку. Як правило, такий газ має теплотворну

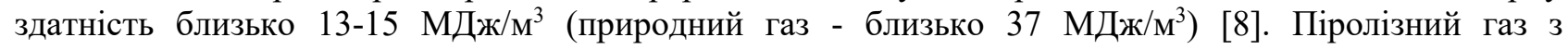
підвищеним вмістом вуглеводневих компонентів (що призводить до високої теплотворної здатності) використовується, як правило, як джерело енергії. Очищений піролізний газ може використовуватися як джерело енергії в печах, як паливо для промислових парових котлів, і в якості газоподібного палива в двигунах внутрішнього згоряння і газових турбінах [9].

Якщо пари піролізу охолоджуються швидко, виходить темно-коричнева рідина, яка називається біооливою або біонафтою. Біонафта, отримане з біомаси, являє собою складну суміш 3 води (як правило, 20-30 \% за вагою в залежності від вихідної сировини), а також карбоксильних кислот, вуглеводів та ін. [10]. Біонафта містить різну кількість органічних кислот, і це викликає корозію матеріалів (наприклад, сталі та алюмінію). Проте, різні хімічні речовини, що містяться в біонафті, можуть бути вилучені і використані для хімічної і харчової промисловості. За даними [11], хімічна речовина, яка в даний час виходить з біонафти, включає поліфеноли (використовуються для виробництва смоли), кальцій i магній, ацетати, а також інші (використовувані в харчовій промисловості). Відповідно, біонафта може мати різні застосування. За даними [12], біонафта може бути основним продуктом процесу піролізу.

Для того, щоб виробляти біопалива біонафта має бути модифіковано. В середньому біонафти володіють низькою, в порівнянні з бензином (44 МДж/кг) і дизельним паливом (42 МДж/кг), теплотворною здатністю (близько 20 МДж/кг) [13]. Проте, в [14] встановлено, що одержана ними біонафта без переробки може бути використано як паливо для промислових парових котлів і печей. Вона транспортабельна і може зберігатися в великих кількостях. Отже, немає необхідності використовувати його безпосередньо після отримання. Енергія, отримана з використанням біопалива, зазвичай називається «зеленої енергією». Вона може бути використано як «чисте» паливо для виробництва електроенергії і тепла від невеликих стаціонарних дизельних двигунів, газових турбін i котлів. Крім них спектр хімічних речовин, які можуть бути вилучені або отримані, містить в тому числі харчові ароматичні сполуки, смоли агрохімікатів, мінеральних добрив, а також з'єднань, що вимагають використання засобів контролю викидів [15]. 
Ококсованний залишок, або так зване біовугілля, $є$ третім продуктом піролізу біомаси. Біовугілля має властивості багато в чому аналогічні вугіллю. Біовугілля сприяє утворенню ароматичних поліциклічних вуглеводнів (ПАВ) протягом піролізу біомаси, особливо при низькій температурі, має теплотворну здатність близько 26 МДж/кг [16]. Ця властивість біовугілля також робить його цікавим продуктом для виробництва енергії. Авторами [17], встановлено, що отримане під час піролізу біовугілля в енергетичній перспективі може бути використане як добавка у вихідне паливо або для його заміни, а також у вигляді брикетів для місцевого палива. Активоване вугілля може бути виготовлений практично 3 будь-яких носіїв вуглецю, але найбільш часто використовуваною сировиною $є$ деревина і кам'яне вугілля. Одна зі сфер промисловості великих споживачів активованого вугілля - очищення води, повітряні фільтри для промислового застосування та автотранспорту. Біовугілля може замінити нафту, і його можна збагатити до активного вуглецю [18].

Таким чином, на даний момент проведені об’ємні дослідження процесів піролізу. Але проблема полягає в тому, що в даний час відсутні надійні математичні моделі для опису процесів піролізу різних видів рослинної біомаси. Для подальших досліджень в ІФНТУНГ передбачається використання в конвертованих на газ дизельних двигунах сумішей природного та піролізного газів. Тому для того, щоб встановити теплоту згорання альтернативного газового палива для конвертованого на газ дизельного двигуна необхідно провести експериментальні дослідження складових піролізного газу в заданих діапазонах зміни основних технологічних параметрів.

\section{ЦІЛЬ ТА ЗАДАЧІ ДОСЛІДЖЕННЯ}

Ціль роботи - дослідження енергетичної цінності газоподібних продуктів піролізу різних видів рослинної біомаси.

Для вирішення вказаної цілі виносяться такі задачі:

- теоретично дослідити основні характеристики зразків типової лісової та водної рослинної біомаси України;

- дослідити експериментально склад газоподібних продуктів піролізу різних видів рослинної біомаси для різних температур;

- встановити нижчі теплотворні здатності газоподібних продуктів піролізу зразків типової лісової та водної рослинної біомаси України.

\section{РЕЗУЛЬТАТИ ДОСЛІДЖЕНЬ}

\section{Загальна характеристика рослинної біомаси Украӥни}

Приблизно 20 \% території України займають мішані ліса, які одержали назву Лісової зони або Полісся. Північна межа зони співпадає з північнім кордоном України, а південна межа лісостепу проходити через Львів - Житомир - Київ - Конотоп - Глухів. Природну рослинність складають лісові, лугові та болотні види. Великі площі зайняті мішаними та хвойних лісами, тут ростуть соснові, сосново-дубові, дубово-грабові та вільхові лісі.

Приблизно 35 \% території України займає Лісостепова зона. Лісостепова зона простяглася від Прикарпаття до Сходу. Північна межа співпадає із Поліссям, а південна - лінія Котовськ - Полтава Куп'янськ. У лісостепу переважають широколистяні ліси, головним чином діброви (дуби скельний і звичайний); з чагарників: дерен, граб; з трав: ковела, типчак.

Близько 40 \% території України припадає на Степову зону. Степова зона простягається від лісостепу на південь до Кримських гір i Чорного та Азовського морів. Дерева найчастіше зустрічаються на півночі зони, а кущі по всій території. Рослинність: дуб пухнастий, клен польовий; 3 чагарників: граб, шипшина; з трав: альпійка, осока.

Приблизно 5 \% території - зона Карпатських гір. Зона Карпатських гір розташована на південному заході країни. Рослинність: тис ягідний, водяний горіх, сосна кедрова європейська, сосна звичайна, ялівець, ясенець білий.

\section{Характеристика досліджуваних видів рослинної біомаси}

Акаиія

Акацію широко культивують по всій Україні, найбільші площі ії насаджень зосереджені в Лісостепу і Степу. Трапляється в парках, садах, полезахисних і протиерозійних смугах, у захисних насадженнях уздовж доріг, поблизу пасік тощо. Вона виключно терпима до грунту щодо родючості, солоності і низького рівня $\mathrm{pH}$ або сезонних заболочених грунтів, що робить акацію дуже підходящої для реабілітації деградованих земель. Поверхнева коренева система дозволяє ій рости на малопотужних грунтах. Деревина має відносно високу питому вагу $(600-800$ кг/м³). Придатна для виготовлення побутових меблів. Деревина ідеальна для заготівлі дров, легких будівельних робіт, а 
також перспективна для високоякісної целюлози. Деревне вугілля, що отримується з акації, не важке і добре горить без диму або іскор, а також має високу енергетичну цінність.

\section{Лiщина (Corylus avellana)}

Ліщина - це кущ 2-4 м заввишки. Кущі ліщини надзвичайно поширені по всій Україні, крім крайнього півдня. Ліщина росте в підліску листяних і мішаних лісів, це - тіньовитривала рослина, гілки якої дугоподібно розходяться в різні боки, утворюючи конусоподібну крону. Цвіте у березні квітні, плоди достигають у серпні. Завдяки високому вмісту жирів і білків плоди ліщини мають високу калорійність і є цінним продуктом харчування. Цей вид стійкий до високого ступеня посушливості і вступає в боротьбу з сільськогосподарськими культурами. Він може рости без захисту i може бути використаний для захисту полів і фермерських господарств. Ліщина пускає коріння глибоко і широко і формує вузлики, коли присутні відповідні штами бактерій, однак у багатьох частинах світу ліщина вважається видом бур'янів. Використовують як дієтичний і лікувальний засіб при шлунково-кишкових захворюваннях. Гілки можна використовувати в якості дров, сировини для газифікації або гранул палива, так як забезпечується великий вихід летючих речовин в якості пального газу.

\section{Eлодея (Elodea)}

Елодея (Elodea) або «водяна чума» - рід багаторічних водних рослин родини водокрасових (Hydrocharitacea), одна 3 найпоширеніших в Україні та на Землі водних рослин. Зазначена водяна рослина $\epsilon$ надзвичайно пристосованою до будь-якого водного середовища, $\epsilon$ вкрай невибагливою та відрізняється надзвичайно високими темпами збільшення біомаси: до 5 \% за добу. Пускає довгі, сильно розгалужені стебла, що ростуть надзвичайно швидко і досягають нерідко довжини понад два метри. Елодея в XIX столітті була занесена до Європи (вперше з'явилася в 1836 році в Ірландіі), де надзвичайно швидко i широко розселилася (звідси назва «водяна чума»). Зарості елодеї перешкоджають судноплавству і рибальству. Зелена маса елодеї використовується на корм худобі і як добриво. Так як до якості води рослина абсолютно не вимоглива, то в природному середовищі воно живе практично у всіх, навіть стоячих, водоймах. Елодея без проблем може зростати як в м'якій, так і в жорсткій воді, а також при різному рівні $\mathrm{pH}$. Зазначена водяна рослина створила велику проблему для країн Європи та України через іiі швидке розповсюдження і негативний вплив на екосистеми, рибальство і навіть судноплавство, причому щороку масштаби забруднення поверхні води суттєво збільшуються.

\section{Мікроиистіс синьо-зелений (Microcystis aeruginosa)}

Мікроцистіс синьо-зелений - це водорість роду Мікроцистіс (Microcystis) родини Мікроцистеві (Microcystiaceae) класу Хроокоокковые (Chroococcales) відділу синьо-зелені водорості (Cyanophyta). Надзвичайно розповсюджені в Україні та Європі, являються переважаючим видом водоростей в прісних водоймищах, дуже розповсюджені і в морській воді, поширені і на вологих грунтах. Прадавні бактерії, до яких найбільш близькими $є$ синьо-зелені водорості, виникли близько 3,5 млрд. років тому. Ціанобактерії здатні до оксигенного фотосинтезу. Саме завдяки синтезу і накопиченню оксигену через життєдіяльність Суanophyta 2,4-2,5 млрд. років тому сталась глобальна зміна складу атмосфери Землі, що створило передумови для розвитку сучасних форм життя.

Клітка синьо-зелених водоростей складається з клітинних покривів і протопласта, що включає зовнішню мембрану (плазмолему) і цитоплазму з різними цитоплазматичними структурами. Клітинні оболонки синьо-зелених водоростей жорсткі, виконують опорну і захисну функції; в них виявлені пектини, вуглеводи, амінокислоти, жирні кислоти, ліпополісахариди та ін.

Зазначені водорості призводять до інтенсивного «цвітіння» водоймищ в Україні та Європі, причому щороку масштаби забруднення поверхні води суттєво збільшуються. Розповсюдження синьо-зелених водоростей призводить до гниття води, руйнування водних екосистем та загибелі річок та озер.

\section{Планування експериментальних досліджень процесу піролізу}

Метою експериментальних досліджень $є$ встановлення основних закономірностей одержання складових піролізного газу, в процесі регульованого термічного розкладання рослинної біомаси, для використання його в якості палива в газових сумішах для конвертованих на газ дизельних двигунів. При цьому доцільним є виділення в результаті досліджень відповідних кожного матеріалу систем параметрів, що визначають вихід кінцевих продуктів. Вирішення цього завдання можливе при реалізації багатофакторного експерименту з відтворенням основних умов протікання досліджуваного процесу.

Складання плану досліджень відповідно відомим положенням теорії планування експерименту створює умови для підвищення достовірності результатів вимірювань і скорочення в багатьох 
випадках обсягу експериментальних досліджень або стендових випробувань. Але застосування сучасних методів планування експериментальних досліджень (наприклад, складання факторних планів) передбачає обов'язкову наявність певного мінімуму відомостей про зв'язки між досліджуваними факторами. Аналіз літератури 3 даної проблеми [8-18] показав, що поки немає достовірних відомостей про характер термічного розкладання рослинної біомаси. Можна тільки стверджувати, що на вихід кінцевих продуктів піролізу впливають температура, темп нагріву сировини, вид рослинної біомаси. Але факторний план гарантує отримання в результаті мінімальної кількості дослідів достовірних значень коефіцієнтів в рівняннях регресії тільки при відомому до початку експериментів порядку регресивного рівняння. Більш того, проведення експериментів 3 використанням факторних планів можливо тільки за досить конкретних теоретичних уявлень про досліджуваний процес.

Якщо ж характер залежностей між основними досліджуваними факторами заздалегідь не відомий, то використання звичайного факторного плану може призвести до помилкових результатів. Так, наприклад, стосовно досліджених процесів термічного розкладання рослинної біомаси можлива наявність локальних експериментів для отримання залежностей частки рідких або газоподібних продуктів від температури. Тому, наприклад, використання моделей першого порядку при складанні планів експерименту буде необгрунтованим, виходячи 3 фізичних уявлень про можливі варіанти розвитку процесів термічної конверсії рослинної біомаси. Відповідно, найбільш правильним буде використання при складанні планів експерименту класичної багатофакторної схеми послідовного проведення дослідів в обраному просторі факторів. Але при цьому потрібно відповідно до загальної теорії планування експерименту проводити досліди не за послідовним, а за випадковим планом, при реалізації якого значення незалежних факторів варіюються, з метою виключення впливу зовнішніх неконтрольованих факторів на результати експерименту, рандомізовано (випадковим чином).

При плануванні досліджень необхідно поставити наступні завдання:

- створити умови для оцінки випадкових похибок вимірювань;

- забезпечити мінімальні величини систематичних помилок і виключити грубі помилок;

- забезпечити збереження стабільності властивостей зразків досліджуваних різновидів рослинної біомаси у всій серії експериментів;

- забезпечення мінімальних відхилень параметрів, що характеризують умови експериментів (вологість, тиск і температури в установках піролізу);

- забезпечення адекватності відтворення характеристик зразків від дослідження до дослідження.

За результатами аналізу літератури [1-7] можна зробити обгрунтований висновок, що 3 точки зору виходу піролізного газу основним вхідним параметром є склад деревної біомаси. Функцією мети в планованих експериментах був обраний склад кінцевих газоподібних продуктів. Основними змінними факторами, що визначають цей склад, є температура зразків біомаси в кінці експерименту, інтервал зміни температури, темп нагріву, склад біомаси. Вибір діапазону зміни температур здійснювався методом послідовних наближень при досягненні умов повної конверсії. Значення темпу нагріву вибиралися виходячи 3 реальних можливостей установок для промислової термічної конверсії рослинної біомаси. Інтервали зміни температур вибиралися виходячи 3 умов, щоб забезпечити максимальну достовірність результатів експерименту. При дослідженнях використовувалися основні різновиди рослинної біомаси, перспективні для використання в Україні. Також при виборі виду рослин ставилася мета отримання максимально можливого діапазону зміни їі структури як сировини, для висновків про вплив індивідуальних властивостей біомаси на вихід піролізного газу.

При проведенні експериментів підтримувалася постійна початкова температура зразків. Всі експерименти проводилися в закритому опалювальному приміщенні при температурі повітря 291-294 К. Для реєстрації температур зразка використовувалися хромель-копелеві термопари. Кількість дослідів при фіксованих чинниках вибиралося не менше п’ятьох.

\section{Методика досліджень}

Матеріалами, вибраними для дослідження, були чотири види рослинних біомас, типових для України. Перед експериментами рослини висушувались, щоб зменшити вміст вологи. Розмір окремих частинок рослин становив близько 5-10 мм в довжину і 1-3 мм в товщину.

Піроліз рослинної біомаси проводився 3 використанням спеціально спроектованої та виготовленої піролізної установки, головною частиною якої є піролізний реактор (рис. 1). Установка складається 3 реактора 3 відбірником піролізного газу (1), компресора для закачування піролізного газу в балони з реактору (2), балонів для піролізного газу (3). Виготовлена установка призначена для 
повільного піролізу. В реакторі виготовлений нагрівальний контур, який підключався до мережі 220 В. Для підтримання заданої температури сила струму змінювалась електричним регулятором. Температури контролювались за допомогою хромель-копелевих термопар з похибкою $\pm 2,0^{\circ} \mathrm{C}$. Після початку виходу піролізного газу, частина газу відводилась для підігріву реактора замість електричного нагрівального контуру. Для підтримання заданої температури кількість газу змінювалась газовим краном. Конденсатор був виготовлений у вигляді ємності 3 гвинтовою спіральною трубкою. В якості теплоносія в охолоджуваній ємності використовувалася вода 3 температурою $12-30^{\circ} \mathrm{C}$, яка періодично оновлювалась по мірі іiї нагрівання. Кількість рослинної біомаси, яка завантажувалась одноразово в реактор складала $5000 \pm 1$ грам. Тривалість часу піролізу (експерименту) становила 2-3 години в залежності від заданої температури нагріву.

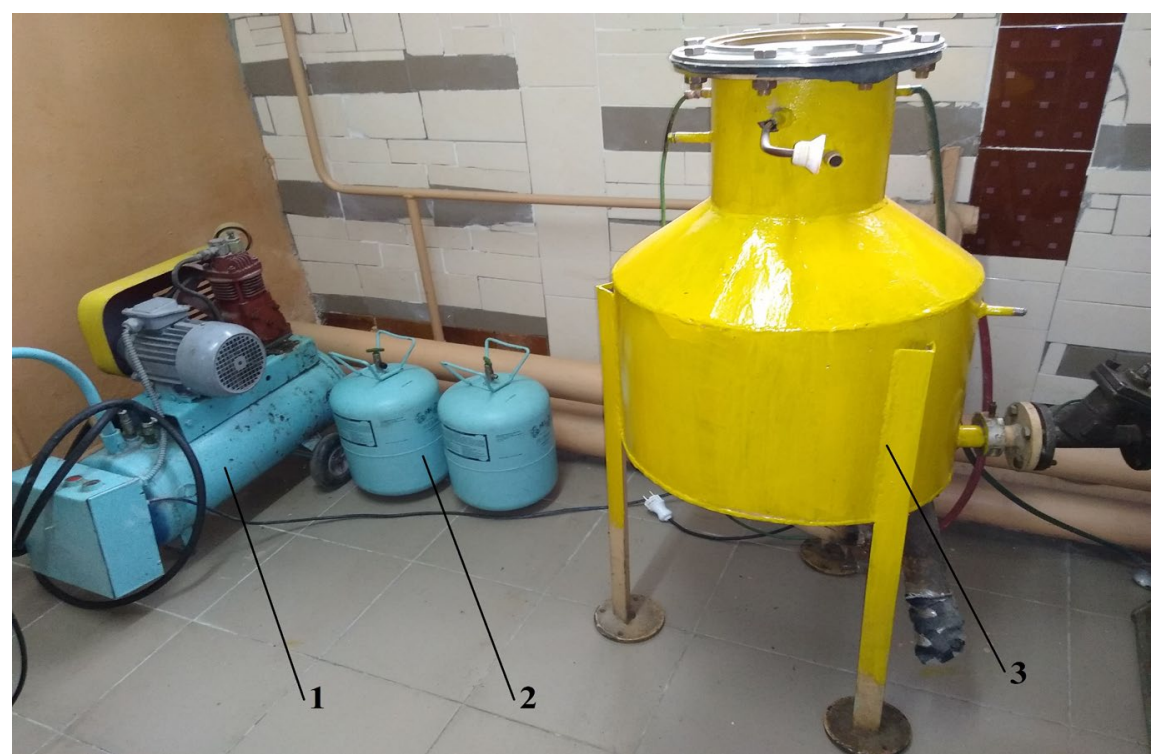

1 - компресор для закачування піролізного газу в балони з реактору; 2 - балони 3 піролізним газом; 3 - піролізний реактор

Рисунок 1 - Зображення експериментальної піролізної установки

Умови експерименту відповідали різним заданим температурам піролізу і видам досліджуваної рослинної сировини. Отриманий піролізний газ поступав в охолоджувач 3 водою $\mathrm{i}$ далі в газовий мішок. 3 газового мішку за допомогою компресора піролізний газ закачувався в балони високого тиску. Зріджений сконденсований продукт збирався в колекторі для піролізної рідини. Вихід різних отриманих продуктів визначався шляхом зважування твердого залишку (біовугілля) і піролізної рідини, які були зібрані під час експерименту. Різниця між завантаженою біомасою та масами біовугілля та піролізної рідини становила кількість піролізного газу. Маса піролізного газу паралельно контролювалась зважуванням газових балонів до і після їнього заповнення. Вихід піролізного газу також визначався у відсотках від маси завантаженої біосировини. Гази, отримані в процесі піролізу, аналізувались на склад на газовому хроматографі NeoCHROM Class B.

Для виключення експериментальних помилок, характерних для серійних досліджень, експерименти проводилися по рандомізованому класичному плану 3 постійним контролем всіх параметрів, необхідних для розрахунку випадкових та систематичних помилок вимірювань. Для того, щоб забезпечити повторюваність результатів експериментів, досліди при постійних факторах проводилися кілька разів, поки фракції виходу продукту не було отримано з розсіюванням не вище $2,0 \%$.

\section{Аналіз піролізних газів}

У цьому дослідженні для визначення факту присутності і процентного виходу продукту були використані якісний і кількісний аналізи газової хроматографії. Газова хроматографія для аналізу якісного і кількісного складу газів має ряд переваг: необхідні обсяги зразка $\left(\sim 1 \mathrm{~cm}^{3}\right)$, невеликий час витримки (близько десяти хвилин), висока точність, швидкість і економічність.

Для аналізу якісного і кількісного складу газів, отриманих в результаті процесу піролізу зразків рослинних біомас був використаний газовий хроматограф NeoCHROM Class B. Метод газової хроматографії є аналітичним методом для виділення сполук на основі їх сорбційного поділу. Визначення складу суміші може бути засноване на визначенні площі піка або висоти піка з'єднання. 
Цей метод дозволяє отримати кількісну і якісну інформацію для кожного з'єднання, присутнього в аналізованої пробі газової фази. Під час експериментів був використаний автоматичний відбір проб і ін'єкції за методом внутрішньої нормалізації. Це - метод калібрування, що часто використовується в газовій хроматографії. Метод заснований на вимірюванні площі кожного піку в хроматограмі. Загальна площа нормована на 100 \%, а кожен пік вказується в процентах від загальної площі.

Газ, отриманий із зразків деревної біомаси, з газового балона вводився в приймальну ємність i аналізувався на газовому хроматографі NeoCHROM Class B. Газом-носієм був водень, а отриманий газ складався головним чином з $\mathrm{CO}, \mathrm{CO}_{2}, \mathrm{CH}_{4}, \mathrm{H}_{2}$ і повітря. Об'ємні концентрації були розраховані методом зовнішнього стандарту, заснованому на лінійній залежності між концентраціями і площею стандартної суміші, вимірюваними хроматографом. До визначення газового складу газовий хроматограф був відкалібрований стандартною сумішшю. В апаратній системі газового хроматографа NeoCHROM Class B були встановлені наступні параметри: температура детектора $100{ }^{\circ} \mathrm{C}$ (детектор теплопровідності); температура інжектора $-80{ }^{\circ} \mathrm{C}$; температура колони - $60{ }^{\circ} \mathrm{C}$; тип колони - з наповнювачем полісорб-1; газ-носій - водень; витрата газу-носія - 40 л/хв.

\section{Результати експериментальних досліджень складу піролізного газу}

При проведенні експериментальних досліджень піролізу рослинної біомаси отримані продукти складалися $з$ твердого біовугілля, піролізної рідини і піролізного газу. Вихід і склад кінцевих продуктів піролізу істотно залежали від умов експерименту. Досліджувався вплив характеристик біомаси і температури піролізу на склад продуктів піролізу і теплоту згорання газу.

Під час процесу піролізу відбувається термічний розклад матеріалів вихідної біомаси. Як уже було зазначено, матеріал рослинної біомаси складається, переважно, 3 трьох видів полімерів: целюлози, геміцелюлози і лігніну. Целюлоза під час нагрівання в основному виділяє $\mathrm{CO}_{2} \mathrm{CO}_{2}, \mathrm{H}_{2}$; геміцелюлоза виділяє $\mathrm{CO}_{2}, \mathrm{H}_{2} \mathrm{O}$ і деякі вуглеводні, а лігнін - $\mathrm{CO}, \mathrm{CO}_{2}, \mathrm{CH}_{4}$ [5-6]. При проведенні досліджень газ, отриманий при піролізі рослинної біомаси, збирався в газовий балон і проводився його аналіз в газовому хроматографі NeoCHROM Class B. Під час експериментів в піролізному газі були зафіксовані оксид вуглецю (чадний газ) $\mathrm{CO}$, діоксид вуглецю (вуглекислий газ) $\mathrm{CO}_{2}$, метан $\mathrm{CH}_{4}$, водень $\mathrm{H}_{2}$, азот $\mathrm{N}_{2}$ i кисень $\mathrm{O}_{2}$. Розподіл компонентів газу, отриманого для різних видів рослинної біомаси при різних кінцевих температурах піролізу, представлено на рис. 2-5. Під час експериментів використовувалась зазначена вище рослинна біомаса: акація, ліщина, мікроцистіс, елодея.

Встановлено, що при температурах $200-350{ }^{\circ} \mathrm{C}$ газова суміш, в основному, складається з СО і $\mathrm{CO}_{2}$, а також містить $\mathrm{N}_{2}$ i $\mathrm{O}_{2}$. Походження $\mathrm{CO}$ i $\mathrm{CO}_{2}$, переважно, залежить від розкладання целюлози $\mathrm{i}$ геміцелюлози.

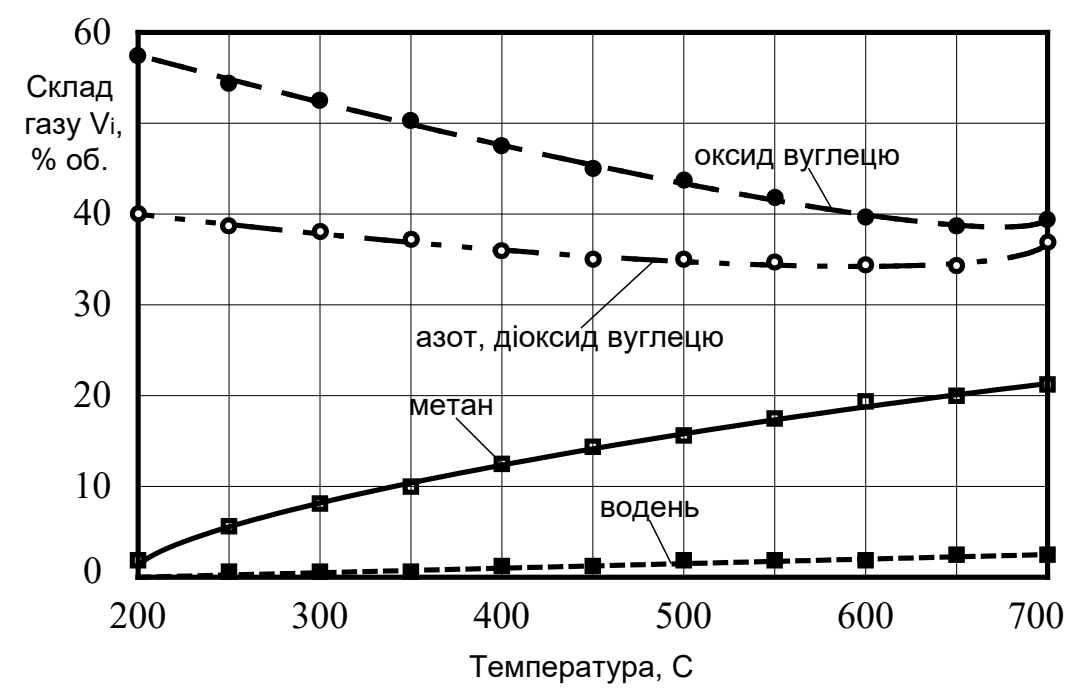

Рисунок 2 - Залежність складу суміші газів, одержаних під час піролізу мікроцистіса, від температури 


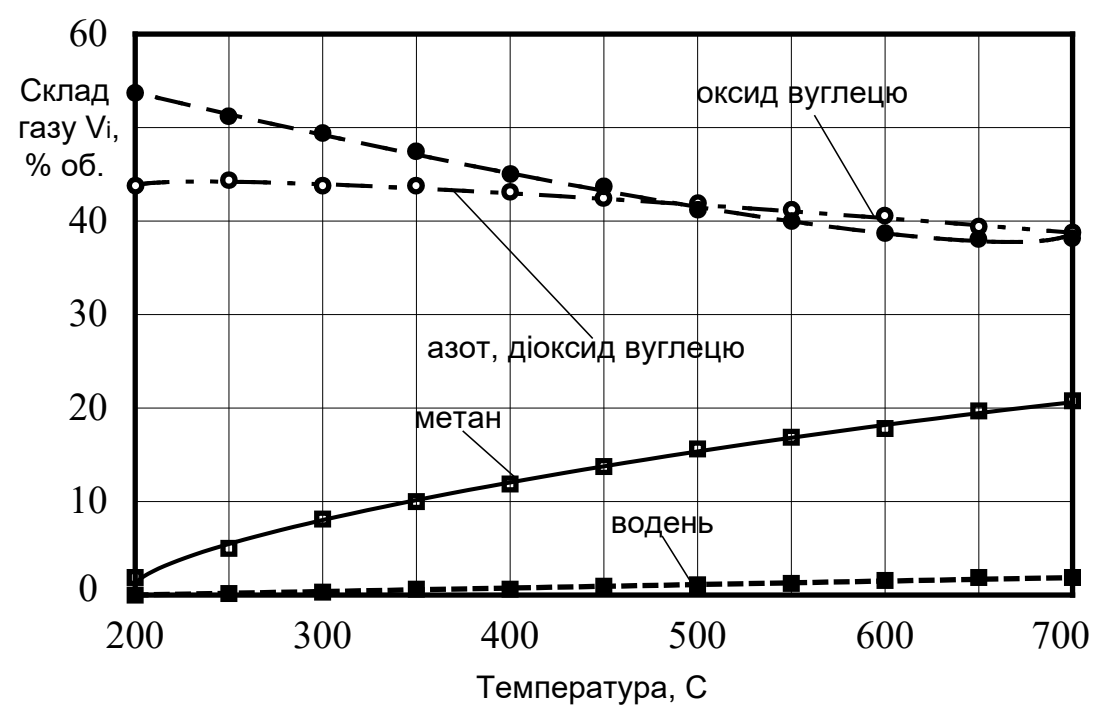

Рисунок 3 - Залежність складу суміші газів, одержаних під час піролізу елодеї, від температури

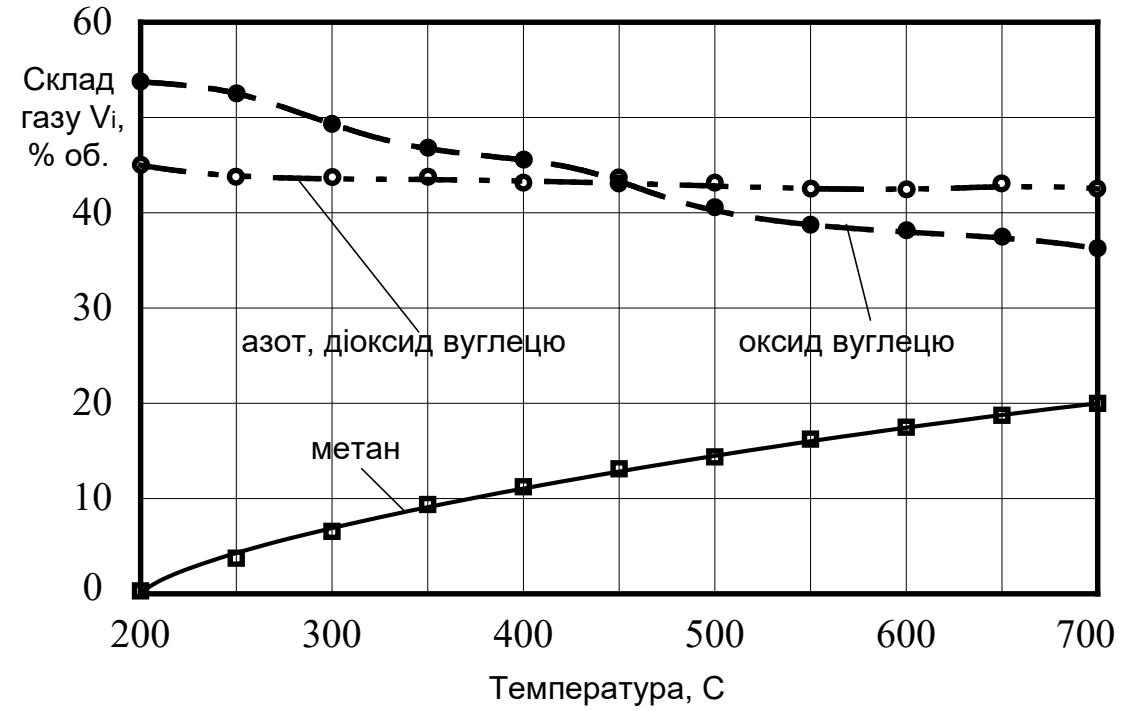

Рисунок 4 - Залежність складу суміші газів, одержаних під час піролізу акації, від температури

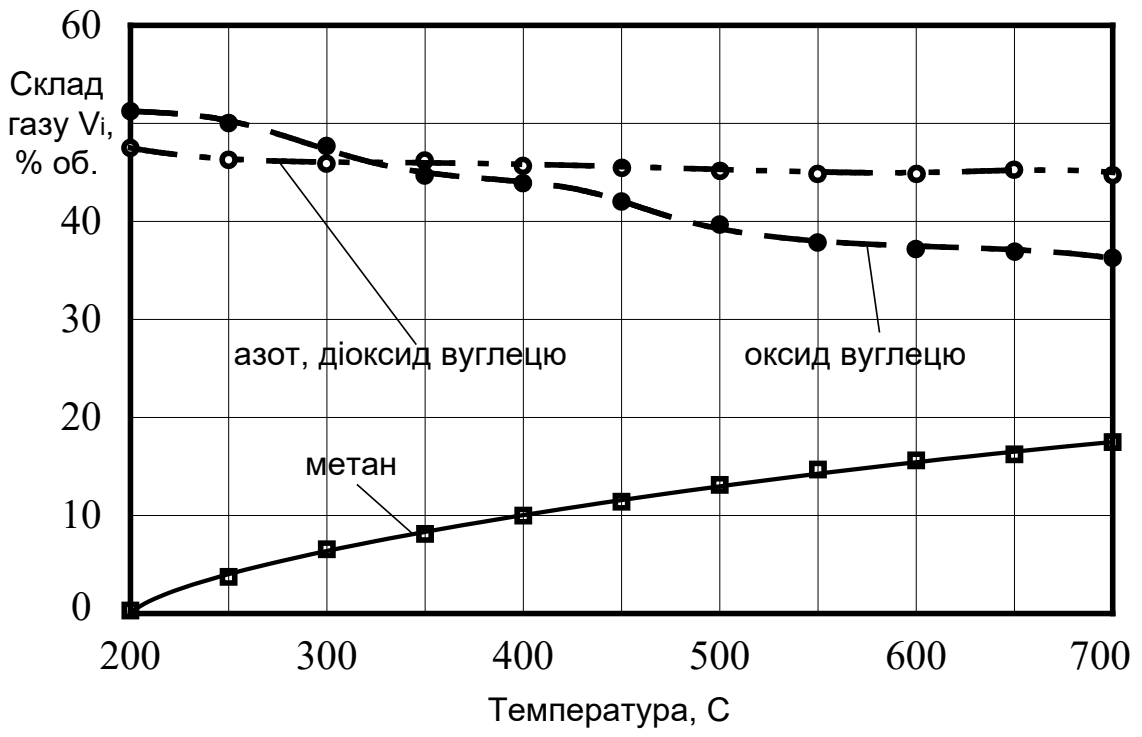

Рисунок 5 - Залежність складу суміші газів, одержаних під час піролізу ліщини, від температури 
Утворення $\mathrm{CO}$ і $\mathrm{CO}_{2}$ при більш високій температурі викликано розкладанням лігніну. При температурах від 200 до $600{ }^{\circ} \mathrm{C}$ вміст $\mathrm{CO}$ незначно зменшується, а вміст $\mathrm{CO}_{2}$ залишається приблизно стабільним. Під час досліджень встановлено, що збільшення температури сприяє інтенсивному виділенню метану $\mathrm{CH}_{4}$. Утворення метану відбувалося за рахунок розкладання лігніну, оскільки його концентрація збільшувалася під час процесу розкладання при високих температурах. Утворення метану відбувається за рахунок виділення метаксильних груп. При цьому вміст повітря зменшується.

Найбільша кількість метану (20-21 \% від обсягу отриманого газу) була виявлена в газових сумішах, що утворювались під час піролізу водної рослини та водорості (елодеї і мікроцистіса) при температурах в діапазоні 600-700 ${ }^{\circ} \mathrm{C}$. Максимальна кількість СО (46-48 \% від обсягу отриманого газу) було отримано при піролізі деревини акації за температур близько 200-300 ${ }^{\circ} \mathrm{C}$. Найбільша кількість $\mathrm{CO}_{2}$ (32-33\% від обсягу отриманого газу) була виявлена в газових сумішах, що утворились при піролізі ліщини за температур 200-500 ${ }^{\circ} \mathrm{C}$. Вміст водню при проведенні експериментів фіксувався при піролізі водних рослин та водорості (елодеї і мікроцистіса) в межах 0,5-2,1 \% 3 тенденцією зростання при збільшенні температури. Встановлено також, що вміст азоту та кисню зі зростанням температури зменшується.

За температур близько $700{ }^{\circ} \mathrm{C}$ вміст метану для мікроцистіса досягнув $21,2 \%$, водню $-2,1 \%$, оксиду вуглецю - $39,8 \%$ (рис. 2). За температури $700{ }^{\circ} \mathrm{C}$ вміст метану для елодеї склав $20,7 \%$, водню - $1,9 \%$, оксиду вуглецю - 38,1 \% (рис. 3). За температур близько $700{ }^{\circ} \mathrm{C}$ вміст метану для акації досягнув 20,2 \%, оксиду вуглецю - 36,9 \%, водню спостерігалось менше 0,1 \% (рис. 4). За температури $700{ }^{\circ} \mathrm{C}$ вміст метану для ліщини склав $17,8 \%$, оксиду вуглецю $-36,8 \%$, водню також спостерігалось менше $0,1 \%$ (рис. 5).

Нижча теплотворна здатність піролізного газу $Q_{H . \Pi \Gamma}($ МДж/кг) визначалась за формулою:

$Q_{H . \Pi \Gamma}=V_{C O} \cdot Q_{H . C O}+V_{C H 4} \cdot Q_{H . C H}+V_{H 2} \cdot Q_{H . H 2}, \quad$ МДж$/ \kappa 2$

де $V_{C O}, V_{C H 4}, V_{H 2}$ - об'ємні частки оксиду вуглецю, метану та водню в піролізному газі;

$Q_{H . C O}, Q_{H . C H 4}, Q_{H . H 2}$ - нижчі теплотворні здатності оксиду вуглецю, метану та водню $(\mathrm{CO}=$ 10,11 МДж/кг, $\mathrm{CH}_{4}=50,0$ МДж/кг, $\mathrm{H}_{2}=120,01$ МДж/кг.

\section{ОБГОВОРЕННЯ РЕЗУЛЬТАТІВ ДОСЛІДЖЕННЯ ТА ВИСНОВКИ}

В результаті проведених розрахунків визначено, що при піролізі водних рослин та водорості (елодеї і мікроцистіса) суміш одержаних газів мала найвищі показники нижчої теплотворної здатності: 17,10-17,15 МДж/кг - для мікроцистіса і 16,45-16,50 МДж/кг - для елодеї. Газ одержаний при піролізі деревини акації мав найвищі показники нижчої теплотворної здатності в межах від 13,8 до 13,85 МДж/кг. Нижча теплотворна здатність пірогазу отриманого зі зразків ліщини перебувала в діапазоні 12,6-12,65 МДж/кг.

Газ із нижчою теплотворною здатністю 11-15 МДж/кг прийнято вважати газовим паливом середнього рівня калорійності і він може безпосередньо використовуватися в двигунах внутрішнього згоряння. Тому метою подальших досліджень є використання одержаного піролізного газу в сумішах 3 метаном (пропан-бутаном) для конвертованих на газове паливо дизельних двигунів.

\section{REFERENCES}

1. Arnold, S., Moss, K., Henkel, M., \& Hausmann, R. (2017). Biotechnological perspectives of pyrolysis oil for a bio-based economy. Trends in Biotechnology, 35, 925-936. https://doi.org/10.1016/j.tibtech.2017.06.003.

2. Bertero, M., de la Puente, G., \& Sedran, U. (2012). Fuels from bio-oils: Bio-oil production from different residual sources, characterization and thermal conditioning. Fuel, 95, 263-271. https://doi.org/10.1016/j.fuel.2011.08.041.

3. Anwar, Z., Gulfraz, M., \& Irshad, M. (2014). Agro-industrial lignocellulosic biomass a key to unlock the future bio-energy: A brief review. Journal of Radiation Research and Applied Sciences, 7, 163173. https://doi.org/10.1016/j.jrras.2014.02.003

4. Linger, J. G., Hobdey, S. E., Franden, M. A., Fulk, E. M., \& Beckham, G. T. (2016). Conversion of levoglucosan and cellobiosan by Pseudomonas putida KT2440. Metabolic Engineering Communications, 3, 24-29. https://doi.org/10.1016/j.meteno.2016.01.005.

5. Arnold, S., Moss, K., Dahmen, N., Henkel, M., \& Hausmann, R. (2018). Pretreatment strategies for microbial valorization of bio-oil fractions produced by fast pyrolysis of ash-rich lignocellulosic biomass. GCB Bioenergy, 11, 181-190. https://doi.org/10.1111/gcbb.12544. 
6. Barakat, A., de Vries, H., \& Rouau, X. (2013). Dry fractionation process as an important step in current and future lignocellulose biorefineries: A review. Bioresource Technology, 134, 362-373. https://doi.org/10.1016/j.biortech.2013.01.169.

7. Lian, J., Garcia-Perez, M., Coates, R., Wu, H., \& Chen, S. (2012). Yeast fermentation of carboxylic acids obtained from pyrolytic aqueous phases for lipid production. Bioresource Technology, 118, 177- 186. https://doi.org/10.1016/j.biortech.2012.05.010

8. Kumar, A. K., \& Sharma, S. (2017). Recent updates on different methods of pretreatment of lignocellulosic feedstocks: A review. Bioresources and Bioprocessing, 4, 7. https://doi.org/10.1186/s40643017-0137-9

9. Abbas-Abadi, M. S., Haghighi, M. N., \& Yeganeh, H. (2013). Evaluation of pyrolysis products of virgin high density polyethylene degradation using different process parameters in a stirred reactor. Fuel Processing Technology, 109, 90-95. http://dx.doi.org/10.1016/j.fuproc.2012.09.042.

10. Guo, X., Wang, S., Wang, Q., Guo, Z., \& Luo, Z. (2011). Properties of bio-oil from fast pyrolysis of rice husk. Chinese Journal of Chemical Engineering, 19, 116- 121. https://doi.org/10.1016/S10049541(09)60186-5

11. Liang, Y., Zhao, X., Chi, Z., Rover, M., Johnston, P., Brown, R., Wen, Z. (2013). Utilization of acetic acid-rich pyrolytic bio-oil by microalga Chlamydomonas reinhardtii: Reducing bio-oil toxicity and enhancing algal toxicity tolerance. Bioresource Technology, 133, 500-506. https://doi.org/10.1016/j.biortech.2013.01.134.

12. Dang, D., Wang, Z., Thygesen, A., Wang, C., Zhou, W., Xing, J., \& Lin, W. (2014). Bio-oil treated by cultivation of Saccharomyces cerevisiae (QH01). BioResources, 9, 2727-2738. https://doi.org/10.15376/biores.9.2.2727-2738

13. Guo, X., Wang, S., Guo, Z., Liu, Q., Luo, Z., \& Cen, K. (2010). Pyrolysis characteristics of bio-oil fractions separated by molecular distillation. Applied Energy, 87, 2892-2898. https://doi.org/10.1016/j.apenergy.2009.10.004

14. Lian, J., Chen, S., Zhou, S., Wang, Z., O'Fallon, J., Li, C. Z., \& Garcia-Perez, M. (2010). Separation, hydrolysis and fermentation of pyrolytic sugars to produce ethanol and lipids. Bioresource Technology, 101, 9688-9699. https://doi.org/10.1016/j.biortech.2010.07.071

15. Demirbas, A. (2007). The influence of temperature on the yields of compounds existing in bio-oils obtained from biomass samples via pyrolysis. Fuel Processing Technology, 88, 591-597. https://doi.org/10.1016/j.fuproc.2007.01.010

16. Mohan, D., Pittman, C. U., \& Steele, P. H. (2006). Pyrolysis of wood/biomass for bio-oil: A critical review. Energy \& Fuels, 20, 848-889. https://doi.org/10.1021/ef0502397

17. Junfeng, H. Runqing, S. Yanqin, S. Jingli, S.C. Bhattacharya, P. Abdul Salam. (2005). Assessment of sustainable energy potential of non-plantation biomass resources in China. Biomass Bioenergy, 29, pp. 167-177, https://doi.org/10.1016/j.biombioe.2005.03.006.

18. Siegel, J. B., Smith, A. L., Poust, S., Wargacki, A. J., Bar-Even, A., Louw, C., ... Baker, D. (2015). Computational protein design enables a novel one-carbon assimilation pathway. Proceedings of the National Academy of Sciences of the United States of America, 112, 3704-3709. https://doi.org/10.1073/pnas.1500545112.

\section{S. Kryshtopa, L. Kryshtopa, M. Hnyp, I. Mykytii, V. Melnyk, T. Dykun. Research of Composition and Heat of Combustion of Pyrolysis Gases as a Fuel for Gas-Converted Engines of Oil and Gas Technological Transport.}

Energy values of gaseous pyrolysis products of typical forest and aquatic plant biomass of Ukraine are investigated. Theoretical researches of main characteristics of samples of typical plant biomass of Ukraine such as acacia, hazel, microcystis, elodea. Methodology and planning of experimental studies of process of pyrolysis of plant biomass are formulated. Experimental researches of composition of gas pyrolysis products of different types of plant biomass for different temperatures were carried according to laboratory conditions. Pyrolysis of plant biomass was carried out using a specially designed and manufactured pyrolysis plant the main part of which is a pyrolysis reactor. Installation made by our department is intended for slow pyrolysis. In research for determine presence and percentage of product yield qualitative and quantitative gas chromatography assays were used. The lower calorific value of gaseous pyrolysis products of samples of typical forest and aquatic plant biomass of Ukraine are calculated. As a result of calculations it was determined that during pyrolysis of aquatic plants and algae mixture of gases obtained had the highest values of lower calorific value: 17,10-17,15 MJ/kg - for microcystis and 16,45-16,50 MJ/kg - for elodea. Gas obtained from pyrolysis of acacia wood had the highest values of lower calorific value in the range of 13.8 to 
$13.85 \mathrm{MJ} / \mathrm{kg}$. The lower calorific value of pyrogas obtained from hazelnut samples ranged from $12.6 \mathrm{MJ} / \mathrm{kg}$ to12.65 MJ/kg.

Keywords: pyrolysis, lower calorific value, gas chromatography, alternative fuels, diesel engine, convertation of engine to gas.

КРИШТОПА Святослав Ігорович, доктор технічних наук, доцент, завкафедрою автомобільного транспорту, Івано-Франківський національний технічний університет нафти і газу,

E-mail: auto.ifntung@,ukr.net, ORCID: http://orcid.org/0000-0001-7899-8817

КРИШТОПА Людмила Іванівна, кандидат технічних наук, доцент, доцент кафедри автомобільного транспорту, Івано-Франківський національний технічний університет нафти і газу, Еmail: 1.i.kryshtopa@mail.ru, ORCID: http://orcid.org/0000-0002-5274-0217

ГНИП Марія Михайлівна, аспірант, кафедра автомобільного транспорту, Івано-Франківський національний технічний університет нафти i газу, E-mail: marichka_gnip@ukr.net, ORCID: http://orcid.org/0000-0003-3662-0941

МИКИТІЙ Іван Михайлович, аспірант, кафедра автомобільного транспорту, ІваноФранківський національний технічний університет нафти i газу, E-mail: 7ivan1@i.ua, ORCID: https://orcid.org/0000-0002-8925-6349

МЕЛЬНИК Василь Миколайович, кандидат технічних наук, доцент, доцент кафедри автомобільного транспорту, Івано-Франківський національний технічний університет нафти і газу, Еmail: melvasnik@yandex.ru, ORCID: http://orcid.org/0000-0002-5793-5486

ДИКУН Тарас Васильович, старший викладач, кафедра автомобільного транспорту, ІваноФранківський національний технічний університет нафти і газу, E-mail: sm@nung.edu.ua

Sviatoslav KRYSHTOPA, Doctor of Technical Sciences, Associate Professor, Head of Department of Automobile Transport, Ivano-Frankivsk National Technical University of Oil and Gas

E-mail: auto.ifntung@ukr.net, ORCID: http://orcid.org/0000-0001-7899-8817

Liudmyla KRYSHTOPA, PhD, Associate Professor, Department of Automobile Transport, IvanoFrankivsk National Technical University of Oil and Gas, E-mail: 1.i.kryshtopa@mail.ru, ORCID: http://orcid.org/0000-0002-5274-0217

Mariia HNYP, Postgraduate student, Department of Automobile Transport, Ivano-Frankivsk National Technical University of Oil and Gas, E-mail: marichka_gnip@ukr.net, ORCID: http://orcid.org/0000-0003-3662-0941

Ivan MYKYTII, Postgraduate student, Department of Automobile Transport, Ivano-Frankivsk National Technical University of Oil and Gas, E-mail: 7ivan1@i.ua, ORCID: https://orcid.org/0000-00028925-6349

Vasyl MELNYK, PhD, Associate Professor, Department of Automobile Transport, Ivano-Frankivsk National Technical University of Oil and Gas, E-mail: melvasnik@yandex.ru, ORCID: http://orcid.org/00000002-5793-5486

Taras DYKUN, Senior Lecturer, Department of Automobile Transport, Ivano-Frankivsk National Technical University of Oil and Gas, E-mail: sm@nung.edu.ua 